\title{
KETIMPANGAN SPASIAL DAN KESENJANGAN INTERNET, ECOMMERCE SERTA EBANKING TAHUN 2017
}

\author{
Studi Kasus di Provinsi Aceh
}

\author{
(Spatial inequality and the Internet, Ecommerce, Ebanking divide in 2017) \\ Case Study in Aceh Province
}

\author{
Muhammad Abrar ${ }^{1}$ \\ ${ }^{1}$ Universitas Airlangga (Unair), Indonesia \\ Sidotopo Wetan I D no 62, Surabaya \\ E-mail: 08.5730@stis.ac.id
}

\begin{abstract}
ABSTRAK
Ketimpangan spasial telah menjadi salah satu agenda utama dalam pembangunan berkelanjutan di negara-negara berkembang. Sebagai negara berkembang, Indonesia saat ini mengalami pertumbuhan dalam penggunaan Teknologi Informasi dan Komunikasi (TIK), tetapi mengalami pembangunan regional yang tidak merata dalam beberapa tahun terakhir. Dalam peneilitian ini digunakan tiga ukuran ketimpangan spasial yang terkait dengan akses internet, ecommerce dan ebanking yaitu: ekonomi, modal manusia, dan infrastruktur telekomunikasi. Metode yang digunakan adalah analisis deskriptif dan regresi logit. Hasil analisis deskriptif menunjukkan penetrasi internet, ecommerce, dan ebanking masih terkonsentrasi di ibukota Provinsi, Kota Banda Aceh. Ketidaksetaraan akses internet berdasarkan jenis kelamin, usia, pendidikan, aktivitas, kepemilikan $\mathrm{HP}$, penggunaan komputer, infrastruktur telekomunikasi, pengeluaran perkapita dapat memperdalam dan melebar di wilayah perkotaan-pedesaan. Hasil analisis menggunakan regresi logit menunjukkan bahwa individu yang memiliki kecenderungan lebih besar untuk penetrasi internet, ecommerce dan ebanking memiliki karakteristik bekerja, pengeluaran perkapita tinggi, memiliki HP, menggunakan komputer, lulus perguruan tinggi serta tinggal di daerah perkotaan dan memiliki infrastruktur telekomunikasi yang memadai.
\end{abstract}

Kata kunci: Ketimpangan spasial, internet, ecommerce, ebanking, Provinsi Aceh.

\section{ABSTRACT}

Spatial inequality has become one of the main agendas in sustainable development in developing countries. As a developing country, Indonesia is currently experiencing growth in the use of Information and Communication Technology (ICT), but has experienced uneven regional development in recent years. In this study three measures of spatial inequality are used related to internet access, ecommerce and ebanking, namely: economy, human capital, and telecommunications infrastructure. The method used is descriptive analysis and logit regression. Descriptive analysis results show internet penetration, ecommerce, and ebanking are still concentrated in the provincial capital, Banda Aceh City. Inequality of internet access based on gender, age, education, activity, cell phone ownership, computer use, telecommunications infrastructure, per capita expenditure can deepen and widen in urban-rural areas. The results of the analysis using logit regression show that individuals who have a greater tendency for internet penetration, ecommerce and ebanking have the characteristics of working, high per capita spending, owning a cell phone, using a computer, graduating from college and living in an urban area and have adequate telecommunications infrastructure.

Keywords: Spatial inequality, internet, ecommerce, ebanking, Aceh Province.

\section{PENDAHULUAN}

Revolusi industri 4.0 ditandai dengan pesatnya perkembangan pemanfaatan teknologi digital di berbagai bidang. Perubahan industri terkini terjadi dengan dukungan revolusi digital dan memadukan berbagai jenis teknologi. Fenomena pesatnya perkembangan teknologi informasi adalah tantangan tersendiri bagi perkekonomian di Indonesia. Pasar digital semakin mendekatkan pembeli dan penjual. Usaha ecommerce mampu bertahan di pasaran di tengah isu daya beli masyarakat yang lesu dan banyak usaha ritel yang tutup. Perkembangan dunia digital di Indonesia kini semakin berkembang pesat. Ada sekitar 132 juta orang telah terhubung dengan jaringan internet (Asosiasi Penyelenggara Jasa Internet Indonesia (2016).

Jika kita bandingkan dengan provinsi lain di Indonesia, maka tingkat penetrasi internet di provinsi Aceh berada di urutan ke-29 dari 34 provinsi di Indonesia (BPS,2017). Dengan persentase 460 
individu pengguna internet sebesar $17,32 \%$, meningkat $2,16 \%$ dari tahun sebelumnya. Angka ini sangat jauh dari rata-rata pengguna internet di Indonesia yaitu sebesar $25,37 \%$ pada periode yang sama. DKI Jakarta sebagai ibukota negara masih menjadi provinsi dengan tinggkat penetrasi internet tertinggi di Indonesia yaitu 50,14\%. Hal ini sejalan dengan penelitian yang dilakukan Sujarwoto dan Gindo Tampubolon (2016) menyoroti kesenjangan geografis di seluruh kabupaten kota. Sebagian besar kabupaten daerah perkotaan di Jawa Tengah, Kalimantan Timur, dan Sumatera Utara memiliki akses internet yang lebih luas daripada daerah lain di Indonesia, khususnya Papua, Sulawesi, dan pulau-pulau kecil di seluruh Maluku dan Ambon.

Pengguna ecommerce dan ebanking di Indonesia juga tumbuh signifikan seiring dengan berkembangnya akses internet. Jumlah usaha ecommerce mencapai angka 26,2 juta berdasarkan hasil Sensus Ekonomi (SE) 2016, naik 17 persen dibandingkan hasil SE 2006. Sementara itu, jumlah nasabah pengguna ebanking meningkat 270 persen dari 13,6 juta nasabah pada tahun 2012 menjadi 50,4 juta pada tahun 2016 berdasarkan laporan Otoritas Jasa Keuangan (OJK). Bisnis ecommerce dan ebanking ini masih akan terus berkembang dalam beberapa tahun mendatang. Ecommerce hanya bisa dikembangkan dengan bantuan ebanking. Ebanking dapat dianggap sebagai fasilitator pembayaran yang dihasilkan oleh ecommerce dan oleh karena itu, tanpa adanya ebanking akan sulit melakukan pembayaran yang berasal dari perdagangan online.

Di negara China, Rusia, India, Meksiko dan Afrika Selatan, serta sebagian besar negara berkembang dan transisi lainnya menunjukkan bahwa perbedaan spasial dan regional dalam aktivitas ekonomi, pendapatan dan indikator sosial telah meningkat dalam dua dekade terakhir ( Kanbur, et al., 2014). Analisis yang lebih dalam tentang jenis ketimpangan spasial ini dan mekanisme yang menjelaskan akses TIK yang tidak setara akan membuktikan kontribusi yang signifikan terhadap upaya negara-negara berkembang untuk mengatasi kesenjangan digital. Sebuah studi sebelumnya yang dilakukan di negara Spanyol (Garín-Muñoz et al., 2019) mengungkapkan bahwa laki-laki meningkatkan kemungkinan menjadi pembelanja online dan semakin tinggi tingkat studi, semakin besar kemungkinan menjadi pembelanja online. Widagdo (2016) beberapa faktor yang sangat menentukan perkembangan ecommerce di Indonesia diantaranya adalah sumber daya manusia, infrastruktur jaringan internet serta infrastruktur ketenagalistrikan. Ketiga faktor tersebut berbanding lurus dengan perkembangan ecommerce di Indonesia. Rahayu dan Day (2015) juga meneliti adopsi ecommerce UMKM di Indonesia. Sebelas variabel diusulkan sebagai faktor yang mempengaruhi UKM dalam mengadopsi ecommerce yang diatur dalam empat kelompok, yaitu: faktor teknologi, faktor organisasi, faktor lingkungan dan faktor individu.

Selain itu, Norris (2001) juga berpendapat peningkatan penggunaan internet juga berpotensi untuk memperburuk ketimpangan spasial yang ada di negara berkembang dan transisi. Kesenjangan digital geo-spasial dapat muncul sebagai konsekuensi dari munculnya TIK. Dalam penerimaan teknologi dilakukan dengan menggunakan Technology Acceptence Model (TAM). Teori ini dikemukakan oleh Davis pada tahun 1989 dan dikembangkan lagi oleh beberapa peneliti. Model TAM dilandasi oleh Theory of Reasoned Action (TRA). TRA telah digunakan untuk memprediksi suatu perilaku dalam banyak hal. TRA juga dapat dijelaskan sebagai sebuah model yang mempelajari secara luas psikologi sosial berkaitan dengan perilaku seseorang yang dilakukan secara sadar (Gaur, 2006). Berdasarkan TRA, pengguna suatu sistem ditentukan oleh persepsi individu dan sikap yang pada akhirnya akan membentuk perilaku seseorang dalam penggunaan suatu teknologi informasi.

Penelitian mengenai ekonomi digital masih jarang dilakukan di Indonesia. Kemunculan ecommerce dan ebanking memiliki implikasi ekonomi dan sosial yang penting. Oleh karena itu, perlu adanya kajian mengenai karakteristik pengguna internet, ecommerce dan ebanking dalam menghadapi era revolusi industri 4.0 di Provinsi Aceh tahun 2017. Berdasarkan latar belakang diatas, tujuan yang ingin diangkat dalam penelitian ini adalah melihat karakteristik pengguna internet, ecommece dan ebanking, dan kesenjangannya yang terjadi antar daerah di Provinsi Aceh. Selain itu juga faktor apa saja yang membentuk keputusan individu untuk mengadopsi ketiga layanan tersebut sehingga dapat memberi gambaran langkah apa yang perlu dilakukan oleh pemerintah daerah dan masyarakat Aceh dalam rangka menghadapi era industi 4.0.

\section{METODE}

Data utama yang digunakan dalam penelitian ini adalah data hasil Survei Ekonomi Nasional (SUSENAS) Maret 2017. Susenas merupakan salah satu survei yang dilaksanakan secara rutin oleh 
BPS dengan pendekatan rumah tangga. Pelaksanaan Susenas Maret 2017 mencakup 11.535 rumah tangga sampel yang tersebar di 23 kabupaten/kota di Provinsi Aceh. Dengan jumlah sampel tersebut data yang dihasilkan dapat mengestimasi angka hingga tingkat Kabupaten/Kota. Data Susenas mempunyai informasi yang menggambarkan sosial ekonomi dan karakteristik individu termasuk informasi pemanfaatan internet untuk jual beli dengan sistem online dan ebanking. Dengan menggunakan data Susenas diharapkan mampu diperoleh informasi faktor-faktor apa saja yang dapat mempengaruhi kesenjangan internet, ecommerce dan ebangking di Provinsi Aceh. Unit observasi dalam penelitian ini mencakup penduduk berusia 10 tahun ke atas yang mengakses internet, ecommerce dan ebangking dalam tiga bulan terakhir sebanyak 36.508 individu.

Metode yang digunakan adalah analisis deskriptif dan regresi logistik. Analisis Deskriptif adalah analisis yang dilakukan untuk menggambarkan karakteristik dari sebuah data melaui tabel dan gambar. Regresi logistik memungkinkan memprediksi probabilitas adopsi suatu layanan (internet, ebanking, ecommerce) dengan bantuan sejumlah variabel independen, karakteristik sosial-ekonomi individu. Model jenis ini telah digunakan oleh Serener, 2016 (untuk ebanking). Kesenjangan internet, ecommerce dan ebanking diukur dengan variabel dummy yang menunjukkan akses individu ke internet. Kesenjangan internet menggunakan karakteristik sosial-demografis individu yang memiliki atau tidak memiliki akses ketiga layanan tersebut. Perbedaan akses ke internet terkait dengan individu dan karakteristik mereka, termasuk tingkat pendapatan, pendidikan, pekerjaan, usia dan jenis kelamin (Van Dijk, 2012).

Persamaan regresi model pada masing-masing layanan (internet, ecommerce dan ebanking) dapat ditulis sebagai berikut. Mempertimbangkan seorang individu i yang bertempat tinggal di kabupaten/kota j, modelnya adalah:

$$
\begin{aligned}
& \text { Eij* }=\beta o+\Sigma \beta j W j+\beta i j X i j+\mu j+\epsilon i j \\
& \text { Dimana: } \\
& \text { Eij* = logit }(P(E i j *=1)) \text {, } \\
& \mathrm{Wj} \text { = seperangkat karakteristik kabupaten (Indeks Gini dan rasio elektrifikasi, rasio BTS (Base } \\
& \text { Transceiver Station), rasio sinyal HP dari data Podes } 2014 . \\
& \text { Xij = seperangkat karakteristik individu (jenis kelamin, umur, pendidikan, pekerjaan, sekolah, }
\end{aligned}
$$

\section{HASIL DAN PEMBAHASAN}

Informasi yang terkandung dalam tabel 1. menunjukkan ketiga model secara statistik signifikan dan mampu membedakan antara responden yang menggunakan masing-masing layanan dan yang tidak menggunakan. Model internet dengan benar mengklasifikasikan 88,97 persen kasus yang sesuai, untuk model e-commerce dan e-banking masing-masing adalah 94,03 persen dan 98,16 persen. Dalam hal jenis kelamin, kesenjangan digital untuk semua layanan dan lebih banyak lakilaki pada pengguna internet dan ebanking, namun lebih tinggi wanita pada pengguna ecommerce. Perbedaan terbesar yang terlihat dalam penggunaan ecommerce, dimana wanita memiliki tingkat partisipasi 21,86 poin lebih tinggi daripada pria. Kesenjangan digital berdasarkan kelompok umur menunjukkan individu yang berusia 50 atau lebih dengan tingkat partisipasi terendah (kecuali untuk kasus ebanking dimana tingkat terendah kelompok 10-19 tahun). Berdasarkan tingkat pendidikan, semakin tinggi pendidikan maka semakin tinggi penggunaan internet dan pelayanan. Menurut aktivitas terbanyak penduduk yang bekerja memiliki tingkat penetrasi yang lebih tinggi di semua layanan. Secara lokasi, penduduk Aceh yang tinggal di perkotaan memiliki tingkat partisipasi yang lebih tinggi (kecuali persentase pengguna internet) pada ecommerce dan ebanking. Masyarakat yang memiliki HP dan menggunakan komputer memiliki tingkat penetrasi yang lebih tinggi di semua layanan. Seperti yang diharapkan, tingkat ekonomi individu juga menentukan penggunaan TIK. Semakin tinggi pengeluaran individu perbulan, semakin tinggi tingkat penetrasi. Ini berlaku untuk semua layanan. Hasil dari tabel ini berguna ke arah kebijakan yang seharusnya menjembatani kesenjangan digital. 
Tabel 1. Karakteristik Pengguna dan Marginal Effect

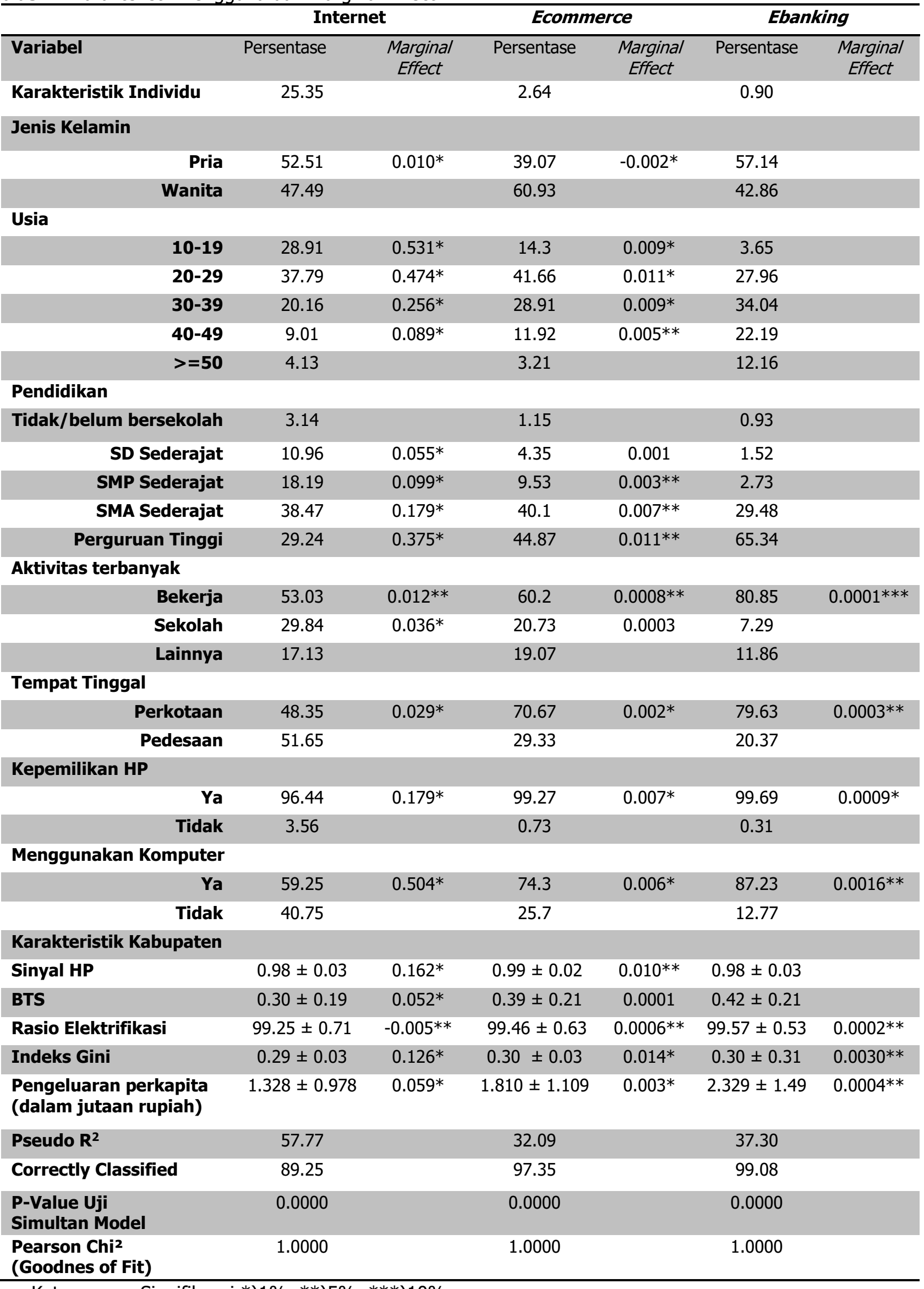

Keterangan: Signifikansi $*) 1 \%, * *) 5 \%, * * *) 10 \%$ 

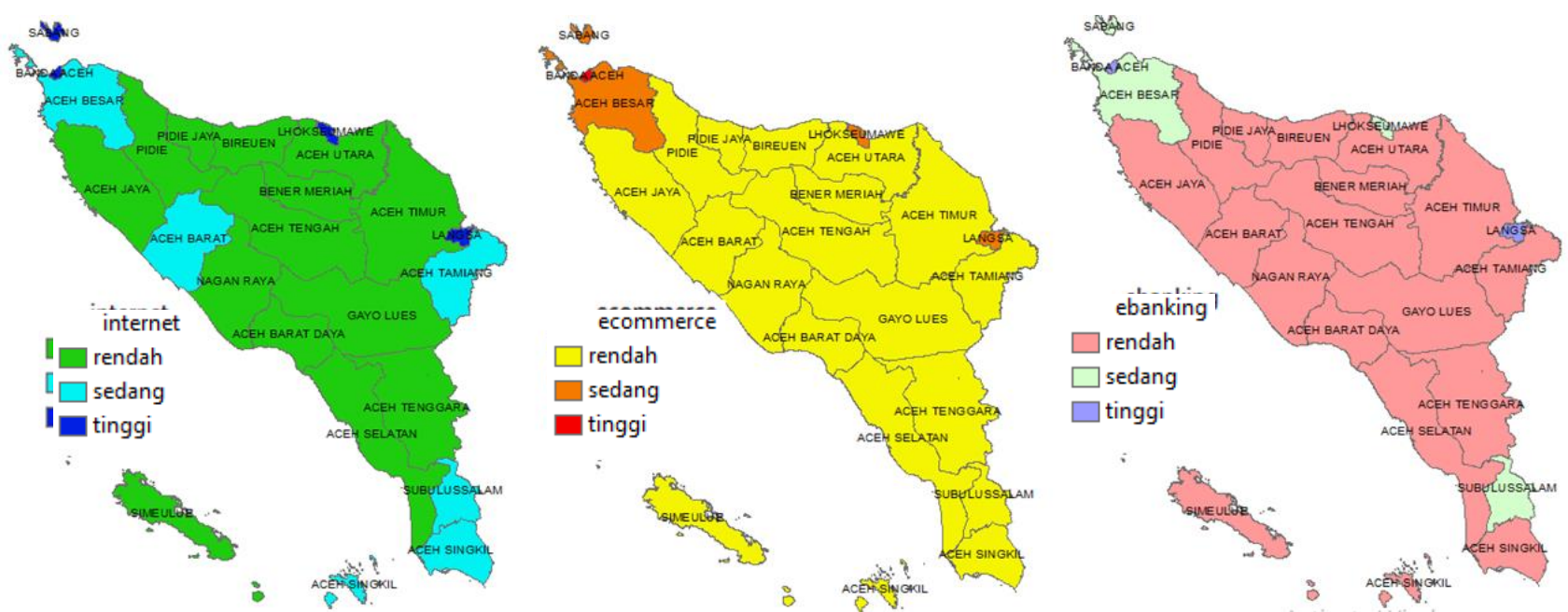

Gambar 1. Distribusi Spasial Pengguna Internet, Ecommerce dan Ebanking Menurut Kabupaten/Kota di Provinsi Aceh, Tahun 2017.

Kesenjangan spasial dalam akses internet, ecommerce dan ebanking dapat diperoleh dari peta pada Gambar 1. yang menyoroti kesenjangan geografis di seluruh kabupaten/Kota. Seluruh kota (kecuali Subulussalam) memiliki akses internet, ecommerce dan ebanking yang lebih luas daripada kabupaten lain di Provinsi Aceh.

Tabel 2. Hasil Analisis Data

\begin{tabular}{|c|c|c|c|c|c|c|}
\hline \multirow{2}{*}{$\begin{array}{l}\text { Variabel } \\
\text { Karakteristik Individu }\end{array}$} & \multicolumn{2}{|c|}{ Internet } & \multicolumn{2}{|c|}{ Ecommerce } & \multicolumn{2}{|c|}{ Ebanking } \\
\hline & Coef & se & Coef & se & Coef & se \\
\hline Pria & $0.157 *$ & 0.044 & $-0.649 *$ & 0.078 & 0.147 & 0.127 \\
\hline \multicolumn{7}{|l|}{ Usia } \\
\hline 10-19 & $3.730^{*}$ & 0.113 & $1.746^{*}$ & 0.239 & -0.366 & 0.423 \\
\hline 20-29 & $3.249 *$ & 0.093 & $1.867 *$ & 0.200 & 0.105 & 0.217 \\
\hline 30-39 & $2.175^{*}$ & 0.093 & $1.781^{*}$ & 0.200 & $0.519 * *$ & 0.207 \\
\hline $40-49$ & $1.007 *$ & 0.099 & $1.130 *$ & 0.211 & $0.437 * *$ & 0.217 \\
\hline \multicolumn{7}{|l|}{ Pendidikan } \\
\hline SD Sederajat & $0.722 *$ & 0.099 & 0.425 & 0.348 & -0.465 & 0.738 \\
\hline SMP Sederajat & $1.118^{*}$ & 0.098 & $0.905^{* *}$ & 0.329 & 0.066 & 0.676 \\
\hline SMA Sederajat & $1.810^{*}$ & 0.099 & $1.566^{*}$ & 0.323 & 0.958 & 0.607 \\
\hline Perguruan Tinggi & $2.566^{*}$ & 0.110 & $1.750^{*}$ & 0.332 & $1.479 * *$ & 0.612 \\
\hline \multicolumn{7}{|l|}{ Aktivitas terbanyak } \\
\hline Bekerja & $0.182 * *$ & 0.056 & $0.295^{* *}$ & 0.101 & $0.457 * *$ & 0.193 \\
\hline Sekolah & $0.494 *$ & 0.085 & 0.112 & 0.145 & -0.178 & 0.317 \\
\hline Tinggal di Perkotaan & $0.418^{*}$ & 0.046 & $0.585^{*}$ & 0.910 & $0.651^{*}$ & 0.168 \\
\hline Memiliki HP & 2.913* & 0.079 & $2.554 *$ & 0.388 & $2.514 * *$ & 1.019 \\
\hline $\begin{array}{l}\text { Menggunakan } \\
\text { Komputer }\end{array}$ & $3.322^{*}$ & 0.586 & $1.265^{*}$ & 0.914 & $1.923 *$ & 0.189 \\
\hline \multicolumn{7}{|l|}{$\begin{array}{r}\text { Karakteristik } \\
\text { Kabupaten }\end{array}$} \\
\hline Sinyal HP & $2.484 *$ & 0.568 & $3.745 * *$ & 1.333 & 0.618 & 2.045 \\
\hline BTS & $0.801^{*}$ & 0.161 & 0.057 & 0.269 & -0.308 & 0.447 \\
\hline Rasio Elektrifikasi & $-0.085^{* *}$ & 0.035 & $0.2271^{* *}$ & 0.073 & $0.543 *$ & 0.134 \\
\hline Indeks Gini & 1.937* & 0.586 & 5.119* & 1.189 & 7.958* & 2.097 \\
\hline $\begin{array}{l}\text { Pengeluaran } \\
\text { perkapita }\end{array}$ & $0.909 *$ & 0.039 & $0.935^{*}$ & 0.067 & $1.195 *$ & 0.111 \\
\hline Constant & $-15.656 *$ & 3.759 & $-50.212 *$ & 7.933 & -83.553 & 14.221 \\
\hline
\end{tabular}




\section{Keterangan: Signifikansi $*) 1 \%, * *) 5 \%, * * *) 10 \%$}

Kesenjangan digital lintas generasi dan jenis kelamin ditunjukkan dari asosiasi positif dan signifikan dari bertambahnya usia dan laki-laki, asosiai negatif dan signifikan pada perempuan untuk ecommerce. Di seluruh model, generasi yang lebih tua dan perempuan (kecuali ecommerce) lebih kecil kemungkinannya untuk mengakses internet daripada generasi yang lebih muda dan laki-laki. Sumber daya manusia dalam bentuk pendidikan secara signifikan terkait dengan akses digital, individu yang telah lulus pada tingkat perguruan tinggi memiliki akses yang jauh lebih luas pada internet, ecommerce dan ebanking. Modal ekonomi juga sangat kuat dan signifikan terkait dengan akses digital. Rumah tangga dengan pengeluaran perkapita bulanan yang lebih tinggi lebih cenderung memiliki akses ketiga layanan daripada mereka yang kurang. Demikian juga, memiliki HP dan menggunakan komputer meningkatkan kemungkinan memiliki akses internet, ecommerce dan ebanking. Kesenjangan geografis dalam akses digital juga ditemukan pada semua model. Penduduk yang tinggal di daerah pedesaan dan kabupaten kemungkinan kecil memiliki akses ketiga layanan tersebut. Adanya fasilitas infrastuktur TIK yang memadai, sinyal HP, BTS dan dialiri listrik juga meningkatkan jumlah pengguna internet, ecommerce dan ebanking di Provinsi Aceh.

\section{KESIMPULAN}

Hasil analisis menggunakan regresi logit menunjukkan bahwa individu yang memiliki kecenderungan lebih besar untuk penetrasi internet, ecommerce dan ebanking memiliki karakteristik bekerja, pengeluaran perkapita tinggi, memiliki HP, menggunakan komputer, lulus perguruan tinggi serta tinggal di daerah perkotaan dan memiliki infrastruktur telekomunikasi yang memadai. Semakin rendah penetrasi layanan di suatu wilayah, variasi perilaku individu akan semakin tinggi sehingga hanya beberapa variabel saja yang signifikan berpengaruh terhadap kecenderungan individu untuk mengadopsi ketiga layanan tersebut. Sumber daya manusia (SDM) yang memiliki kemampuan yang baik dalam teknologi informasi juga akan mendukung pertumbuhan kegiatan bisnis berbasis online. Pendidikan literasi digital dapat menjadi langkah dalam pengembangan sumber daya manusia. Selain itu, penetrasi internet, ecommerce, dan ebanking masih menemui banyak kendala terutama hal infrastruktur. Kendala jaringan komunikasi atau koneksi dapat menghambat kegiatan transaksi online. Kebijakan pemerintah tentu sangat berperan dalam pengembangan pasar digital di Provinsi Aceh.

\section{DAFTAR PUSTAKA}

Asosiasi Penyelenggara Jasa Internet Indonesia. (2017). Penetrasi dan Perilaku Pengguna Internet Indonesia. Jakarta: APJII.

Badan Pusat Statistik. (2016). Sensus Ekonomi 2016. Jakarta: BPS. . (2017). Statistik Kesejahteraan Rakyat Indonesia 2017. Jakarta: BPS.

Garín-Muñoz, T., López, R., Pérez-Amaral, T., Herguera, I., \& Valarezo, A. (2019). Models for individual adoption of eCommerce, eBanking and eGovernment in Spain. Telecommunications Policy, 43(1), 100111.

Gaur, S. S., \& Agrawal, R. (2006). Service quality measurement in retail store context: A review of advances made using SERVQUAL and RSQS. The Marketing Review, 6(4), 317-330.

Kanbur, R., Rhee, C., \& Zhuang, J. (2014). Inequality in Asia and the Pacific: trends, drivers, and policy implications. NewYork: Routledge.

Norris, P. (2001). Digital divide: civic engagement, information poverty, and the Internet world wide. NewYork:Cambridge University Press.

Otoritas Jasa Keuangan. (2017). Laporan Keuangan Publikasi. Jakarta: OJK.

Rahayu, R., \& Day, J. (2015). Determinant factors of e-commerce adoption by SMEs in developing country: evidence from Indonesia. Procedia-Social and Behavioral Sciences, 195, 142-150.

Serener, B. (2016). Statistical analysis of internet banking usage with logistic regression. Procedia Computer Science, 102, 648-653.

Sujarwoto, S., \& Tampubolon, G. (2016). Spatial inequality and the Internet divide in Indonesia 20102012. Telecommunications Policy, 40(7), 602-616.

Widagdo, Prasetyo Budi. (2016). Analisis Perkembangan Ecommerce Dalam Mendorong Pertumbuhan Ekonomi Wilayah di Indonesia. Yogyakarta : Universitas Gajah Mada.

Van Dijk, J.A.G.M. (2012). The evolution of the digital divide: the digital divide turns to inequality of skills and usage. In J Bus, M.Crompton, M. Hildebrandt, \& G.Metakides (Eds.), Digital enlightenment yearbook. 